\title{
Quantity and Seasonal Variation of Propolis Gathering Activity by Craniolan and Italian Honey Bee Hybrid at kafr El-Sheikh. Fathy, H. M. ${ }^{1}$; F. A. A. Badria ${ }^{2}$; A. S. Fatehe ${ }^{3}$ and M. G. M. Ghazy ${ }^{3}$ ${ }_{1}^{1}$ Department of Entomology, Faculty of Agriculture, Mansoura University. ${ }^{2}$ Department of Pharmacognosy, Faculty of Pharmacy, Mansoura University. \\ ${ }^{3}$ Department of Bee research, plant protection research Institute.
}

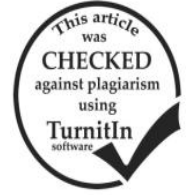

ABSTRACT

This study was conducted in the apiary of bee research - plant protection research institute branch of Sakha - Kafr Elsheikh governorate during the period from the beginning of January 2014 until the end of December 2014 to study the activity in the collecting propolis, according to bee races (Craniolan hybrid and Italian hybrid). The propolis amount collected by the Italian hybrid in spring between $1.14-2.60 \mathrm{~g}$.with a mean value of $1.90 \mathrm{~g}$. Whereas the Propolis amount collected by the Craniolan hybrid ranged between $2.697-6.353 \mathrm{~g}$ with a mean value of 4.56.The Propolis amount collected by Italian hybrid 3.67g ranged between $0.520-2.170 \mathrm{~g}$ in winter with mean $1.223 \mathrm{~g}$, in summer with a mean value of $4.41 \mathrm{~g}$. The highest value in winter season was in Marsh $2.170 \mathrm{~g}$, while the lowest value was in January $0.520 \mathrm{~g}$. Whereas the Propolis amount collected by Carniolan hybrid $8.766 \mathrm{~g}$ ranged between $1.913-3.870 \mathrm{~g}$ in winter with mean $2.923 \mathrm{~g}$. In summer with a mean value of $6.709 \mathrm{~g}$. The highest value in winter season was in February 3.870g, while the lowest value was in January $1.913 \mathrm{~g}$, the highest value in summer season was in July $9.214 \mathrm{~g}$, while the lowest value was in September 3.124g.

\section{INTRODUCTION}

Propolis is a resinous product, which gathered by honeybees from various plant exudates and is collected in beehives. With various botanical and geographical origins, more than 200 compounds have been isolated and identified from propolis (Marcucci, 1995 and Marcucci et al., 2001)

El-Shaarawy (1989) studied the amounts of propolis collected by two hybrids (FI Italian and FI Carniolan). The highest amounts of propolis were gathered during July and August and the lowest was in December and January, while Rybak et al. (1992) found that the seasons of collection (Spring, Summer, Autumn) and the strength of the colony had significant effects on the contents of both types of impurities. The tendency of a colony to produce propolis also affected wax content. Fewer impurities were found in propolis produced in summer and autumn by strong colonies that collected much propolis.

The factors, which trigger propolis collection by the bees, are not completely understood. Some observers have suggested that seasonal factors maybe responsible rather than the availability of propolis (Ashour, 1989). The world now is returning to the use of natural products both in food processing and in the field of medicine (El-Fadaly et al., 1999). Propolis is the source of the majority of the phenolic compounds present in honey. The ethanolic extract of raw propolis contains the bulk of organic constituents, which is incorporated into medicinal and health food products.

Recently, the scientist have been able to prove that propolis is as active and important as our forefathers thought. Propolis is a transformation derivate result when bees gather or feed on tree buds, sap flows, or other botanical sources previously. Therefore, it appears as a mixture of resins, balsams, essential oils, flavonoids, vitamins, minerals and pollen, albeit and appear in more than 300 constituents at different concentrations (Said et al., 2006; Alencar et al., 2007 and De Vecchi and Drago, 2007).
This study aimed to measure the quantity and seasonal variation of Propolis collected by honeybee according to bee races.

\section{MATERIALS AND METHODS}

The experiments of this study were carried out at bee research -plant protection research institute branch of Sakha - Kafr el-sheikh governorate during the period from the beginning of January 2014 until the end of December 2014 to study the activity of bees in collecting propolis, according to bee races (Craniolan hybrid and Italian hybrid)

\section{Propolis collecting}

Two-honeybee hybrid's colonies propolis were collected (Carniolan - Italian). scraping propolis (raw Egyptian propolis) from the hive monthly at the end of each month throughout the season study (Fig. 1). The propolis amount weight was obtained monthly for a year of study. Compared between the amount of propolis obtained from the two hybrids (Carniolan- Italian), the amounts of propolis obtained in different seasons (Winter - Autumn - Spring - Summer)

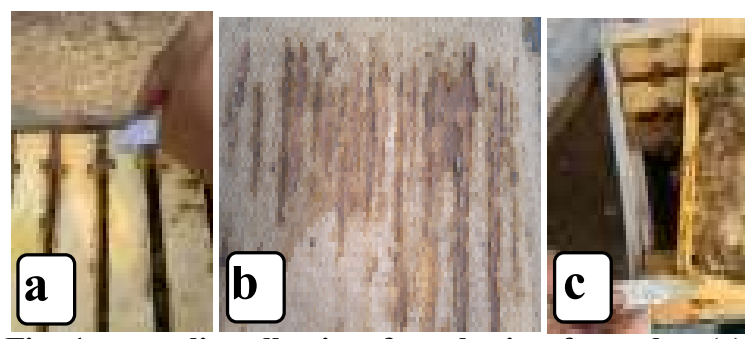

Fig. 1. propolis collecting $\&$ gathering from the: (a) comb top, (b) hives cover, (c) comb sides).

\section{Statistical analysis:}

The statistical analyses of the experimental data were performed using analysis of variance technique (One -Way ANOVA) and LSD (Least Significant Difference) test according to Gomez and Gomez (1984). The SPSS Computer Program for Windows used (Statistical Package of Social Sciences), Standard Version Copyright (C SPSS Inc., 1989 - 1999. 


\section{RESULTS AND DISCUSSION}

\section{Propolis gathering activity:-}

Many authors mentioned that races of honeybees greatly differ in their habit of propolis gathering. In addition, weather conditions are very important, especially temperature and relative humidity in propolis gathering. In Egypt, the amounts of propolis gathered are very low compared to other countries. This seems to due to several factors, mainly due to propolis sources are less distributed under these conditions. Only few scattered trees are found as a propolis source. However, it seems that, there is no control on propolis. These variations greatly vary from colony to another and from season to another according to bee races, available propolis sources and environmental conditions. Comparative studies were carried out between two races. (Carniolan and Italian hybrid) according to their activities in propolis gathering in a whole year (2014).

The results summarized in Table1, 2 and Fig $2,3,4 \& 5$ indicated that the activity of honeybee colonies according to different races in propolis gathering during a whole year, the amounts of collected propolis varies according to months, seasons and bee races several factors are responsible in propolis collection. However, temperature and relative humidity play an important role in process of collecting propolis.

In the present study, the total amount of propolis gathered by Carniolan hybrid colony was $46.93 \mathrm{~g} /$ colony/year, while the total amount of propolis gathered by Italian hybrid was $20.76 \mathrm{~g} /$ colony/year (Table 1). The highest amount of propolis were collected in summer and spring seasons (33, $30 \mathrm{C}^{0}$ and 53, 62\% $\mathrm{RH})$ from Carniolan hybrid and Italian hybrid, respectively. In summer were 20.121 and $7.23 \mathrm{~g} /$ colony, respectively; while in spring were 13.686 and $5.68 \mathrm{~g} /$ colony, respectively. Carniolan hybrid colonies collected amounts of propolis more than Italian hybrid. The total propolis production increase obviously in Carniolan hybrid colonies during July, August and September (Summer season) and reached to 9.214, 7.793 and $3.124 \mathrm{~g} /$ colony/month, respectively. In Spring, the collected amounts of propolis significantly increased per colony averaging according to bee races 13.686 and $5.68 \mathrm{~g} /$ colony in Carniolan hybrid and Italian hybrid, respectively under temperature and relative humidity conditions $\left(30 \mathrm{C}^{0} \& 62 \% \mathrm{RH}\right)$

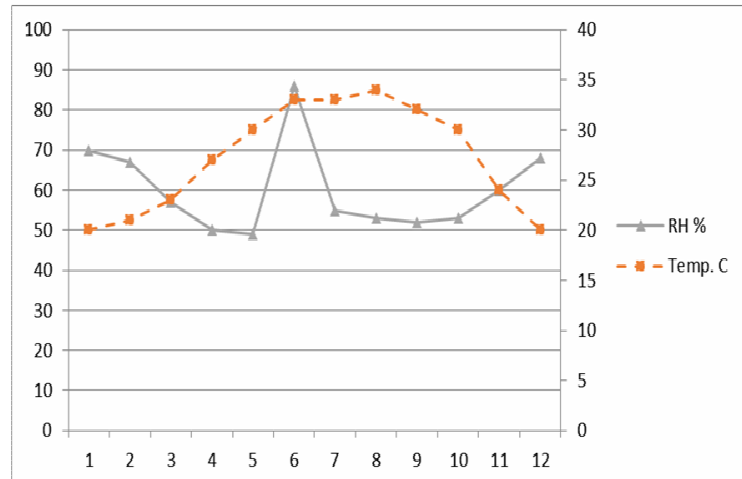

Fig. 2. yearly mean of relativee humidity and temperature

Table 1. Monthly average production of propolis (g/ colony) according to honeybee races under different temperatures and relative humidity conditions during a whole year (2014).

\begin{tabular}{|c|c|c|c|c|c|}
\hline \multirow{2}{*}{\multicolumn{2}{|c|}{ Months }} & \multicolumn{2}{|c|}{ Propolis amounts (g/colony) } & \multicolumn{2}{|c|}{ Mean } \\
\hline & & Carniolan hybrid & Italian hybrid & Temp. $^{0} \mathrm{C}$ & RH\% \\
\hline \multirow{6}{*}{ 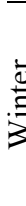 } & Jan. & 1.913 & 0.520 & 20 & 70 \\
\hline & Feb. & 3.870 & 0.980 & 21 & 67 \\
\hline & Mar. & 2.983 & 2.170 & 23 & 57 \\
\hline & Total & 8.766 & 3.67 & 21 & 65 \\
\hline & season $\%$ & 18.68 & 17.68 & 21 & OJ \\
\hline & Mean colony & 2.923 & 1.223 & - & - \\
\hline \multirow{6}{*}{ 告 } & Apr. & 2.697 & 2.600 & 27 & 50 \\
\hline & May. & 4.636 & 1.940 & 30 & 49 \\
\hline & Jun. & 6.353 & 1.140 & 33 & 86 \\
\hline & Total & 13.686 & 5.68 & 30 & 62 \\
\hline & season $\%$ & 29.16 & 27.36 & & \\
\hline & Mean colony & 4.56 & 1.9 & - & - \\
\hline \multirow{6}{*}{$\begin{array}{l}\dot{\Phi} \\
\Xi \\
\vdots \\
\bar{\Xi}\end{array}$} & July. & 9.214 & 3.260 & 33 & 55 \\
\hline & Aug. & 7.793 & 3.260 & 34 & 53 \\
\hline & Sep. & 3.124 & 0.710 & 32 & 52 \\
\hline & Total & 20.131 & 7.23 & 33 & \multirow{3}{*}{53} \\
\hline & Season $\%$ & 42.9 & 34.83 & נJ & \\
\hline & Mean colony & 6.709 & 4.411 & - & \\
\hline \multirow{6}{*}{ 䒠 } & Oct. & 1.243 & 0.680 & 30 & 53 \\
\hline & Nov. & 0.311 & 0.280 & 24 & 60 \\
\hline & Dec. & 2.793 & 3.220 & 20 & 68 \\
\hline & Total & 4.347 & 4.18 & 25 & 60 \\
\hline & season $\%$ & 9.26 & 20.13 & & \\
\hline & Mean colony & 1.449 & 1.394 & - & - \\
\hline \multirow{3}{*}{\multicolumn{2}{|c|}{$\begin{array}{l}\text { Year tota } \\
\text { Year \% } \\
\text { Mean }\end{array}$}} & 46.93 & 20.76 & \multirow{2}{*}{270} & - \\
\hline & & 69.33 & 30.67 & & - \\
\hline & & 3.911 & 1.73 & 27.25 & 60 \\
\hline
\end{tabular}


As indicated from Table 1 and Fig. $2,3 \& 4$, the lowest amount of propolis was collected during Winter and Autumn seasons $\left(21,25 \mathrm{C}^{0}\right.$ and $\left.65,60 \% \mathrm{RH}\right)$ in the two bee races the average amounts of propolis in Craniolian and Italian hybrid were 8.766 and 3.67 $\mathrm{g} /$ colony, In Winter $\left(21 \mathrm{C}^{0}\right.$ and $\left.65 \% \mathrm{RH}\right)$, respectively. While were 4.347 and $4.18 \mathrm{~g} /$ colony in Autumn, respectively $\left(25 \mathrm{C}^{0}\right.$ and $\left.60 \% \mathrm{RH}\right)$. The average amount during October, November and December. (Autumn season) in Carniolan hybrid were 1.243, 0.311 and $2.793 \mathrm{~g} /$ colony, respectively, While in Italian hybrid were $0.680,0.280$ and $3.220 \mathrm{~g} /$ colony, respectively. Therefore, propolis production was highly produced during warm seasons especially in Summer since temperature ranged between 32 to $34 \mathrm{C}^{0}$ and relative humidity ranged between 52 to $55 \% \mathrm{RH}$.

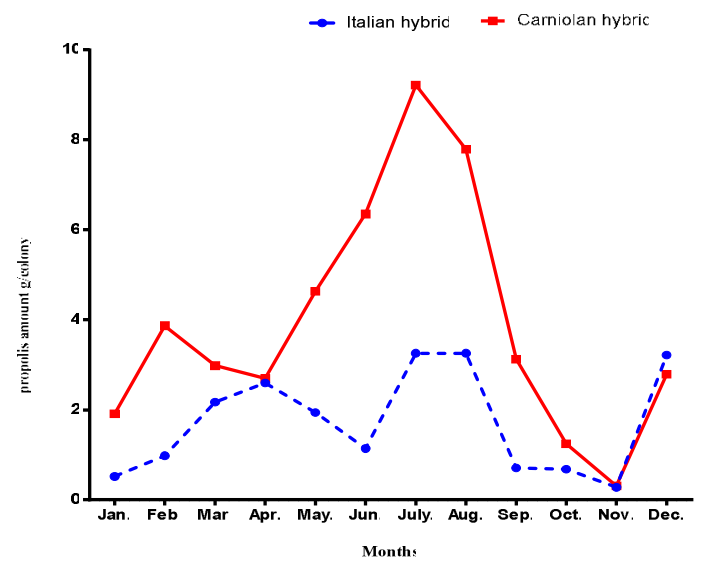

Fig. 3. Activity of propolis gathering by different honeybee races in a whole year (2014)

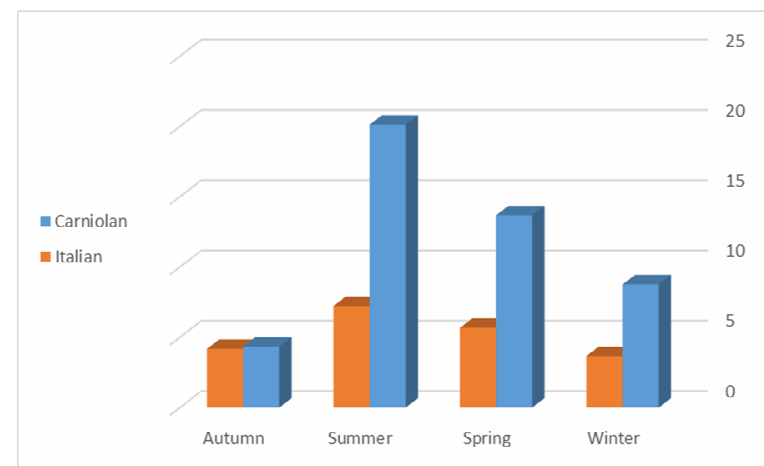

Fig. 4. Seasonal activity of propolis gathering by the different races

From the data presented in Table 1, it could be seen that the yearly average of propolis par colony were 46.93 and 20.76 in Carniolan hybrid and Italian hybrid, respectively.

Statistical analysis, should that the differences between season and bee races as in Table 2, showed highly significant differences among propolis amounts in two - bee races. It was found significant differences between propolis amounts in Winter, Spring and Summer in two bee races, while it was insignificant differences in autumn season in two bee races.
Table 2. Seasonal average per colony of gathered propolis by honeybee races.

\begin{tabular}{lcccc}
\hline \multirow{2}{*}{ aces } & \multicolumn{4}{c}{ Season } \\
\cline { 2 - 5 } & Winter & Spring & Summer & Autumn \\
\hline Carniolan hybrid & $2.922 \mathrm{a}$ & $4.56 \mathrm{~b}$ & $6.709 \mathrm{~b}$ & $1.449 \mathrm{a}$ \\
Italian hybrid & $1.223 \mathrm{a}$ & $1.9 \mathrm{a}$ & $4.411 \mathrm{a}$ & $1.394 \mathrm{a}$ \\
\hline
\end{tabular}

The same letter in every column means insignificant different. $(5 \%)$

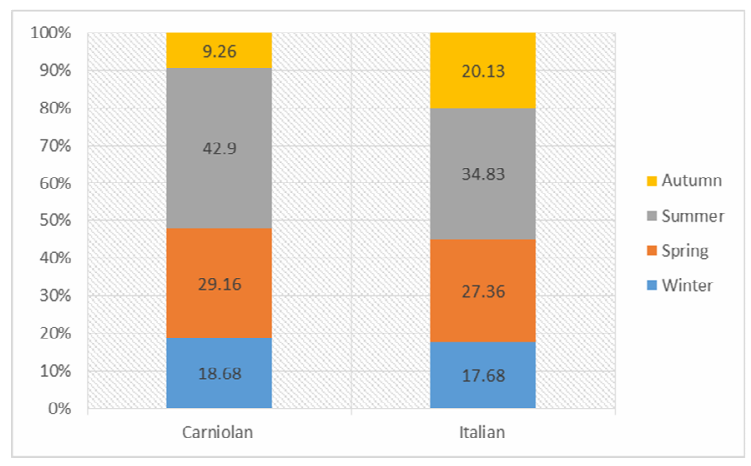

Fig. 5. Seasonal percentages (\%) of propolis gathered by different honeybee races (2014)

The results showed that Carniolan hybrid colonies were more active in collecting propolis than Italian hybrid colonies. Carniolan hybrid Colonies gatherd $69.33 \%$ from the total amounts of propolis of two races, while Italian hybrid colonies gathered $30.67 \%$ from the total amount of propolis. These results are in agreement with (Starostensko, 1968 and Krupicka, 1972), they reported that some races of honeybee collected propolis more active than others. Also, these results are in accordance with those of (Ashour, 1989, El-Shaarawy, 1989 and Ghazala, 1998), they reported that Carniolan hybrid was collected more quantities of propolis than other different bee races.

Generally, Carniolan hybrid race was more active in propolis collecting than Italian hybrid and this may be due to the Carniolan hybrid race is more suitable to collect propolis in Egypt than Italian hybrid race.

\section{REFERENCES}

Alencar, S. M.; Oldoni, T.L.C.; Castro, M. L.; Cabral, I.S.R.; Costaneto, C. M.; Cury, J. A.; Rosalen, P. L. and Ikegaki, M. (2007). Chemical composition and biological activity of a new type of Brazilian propolis: Red propolis. J. Ethnopharmacol. 113: 278-283

Ashour, A. T. (1989). Studies on propolis gathering with reference to its antimicrobial properties. M.Sc. Thesis, Faculty of Agric., Cairo Univ.

De Vecchi, E. and Drago, L. (2007). Propolis antimicrobial activity: what is new? Infez. Med.,15(1):7-15.

El- Fadaly, H.; Hassan, B. and El- Badrawy, E.E (1999). Antifungal potentialities of some plant extracts compared to some yeasts and bacteria. proc. The $2^{\text {nd }}$ Int. Conf. Fungi; Hopes \& Challenges, Cairo, $29^{\text {th }}$ Sept $-1{ }^{\text {st }}$ Oct., Vol. II, pp.95- 105. 
Fathy, H. M. et al.

El-Shaarawy, M. O. (1989). The effect of feeding honeybee colonies $\mathrm{J}$ pollen substitutes on worker brood rearing and citrus honey I Agric. Sci. Mansoura univ., 26(6): 3683 - 3987.

Ghazala, N. M. (1998). Studies on propolis production. M.Sc. Thesis, Fac. of Agric. At Moshtohor Zagazig Univ., $132 \mathrm{pp}$.

Gomez, K.A. and Gomez, A.A. (1984). Statistical procedures for Agriculture Research 2 and edition, John Wiely \& sons. InC

Krupicka, P. (1972). Methods of obtaining propolis. Inter. Symp. Of propolis.Nov. 1972.

Marcucci, M. C. (1995). Propolis: chemical composition, biological properties and therapeutic activity. Apidologie, 26:83-99.
Marcucci, M.; Ferrres, F.; Garcia-Viguera, C.; Bankova, V.; De Castro, S.; Dantas, A.; Valente, P. and Paulino, N. (2001). Phenolic compounds from brazilian propolis with pharmacological activities. J. Ethnophamacol., 74: 105 - 112.

Rybak, C.H., J. Muszynska and Z. Konopacka (1992). Impurities content of propolis as affected by the conditions of its collection. PszczelniczeZeszyty-Naukowe, 36:41-45.

Said, S. A.; Khan, S. A.; Ahmad, I. and Ali, H. S. (2006). Chemical composition of Egyptian and UAE Propolis. Pak. J. Pharm. Sci., 19(1): 58-61.

Starostensko, E. V. (1968). Propolization by bees of various races. Pchelovodstvo, 88(7):30.

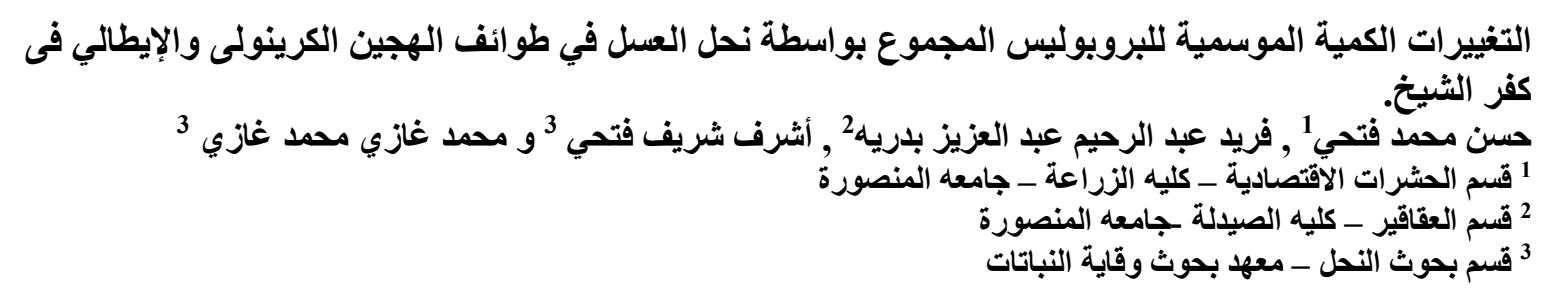

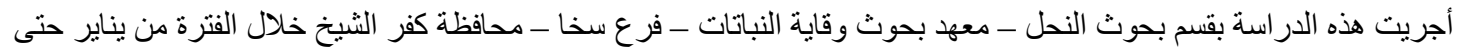
ديسمبر 2014 وذلك لدر اسة نشاط نحل العسل في جمع البروبوليس تبعا لنوع السلالنة (الهجين الكرينيولى، الهجين الإيطالي) منوسط كميه

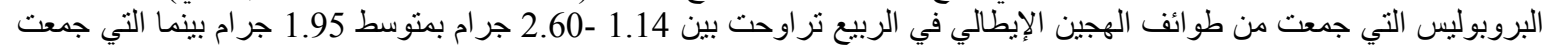

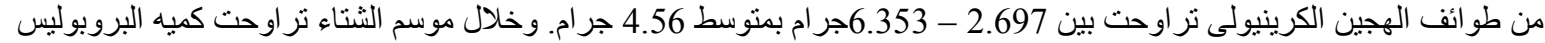

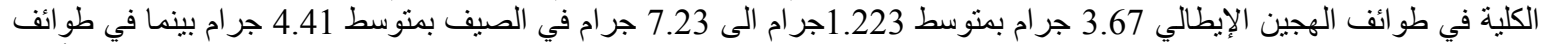

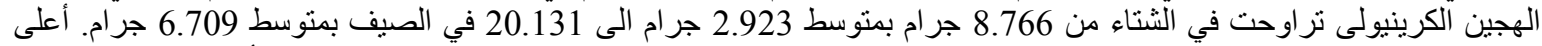

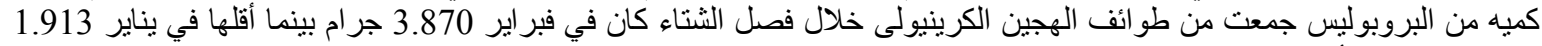

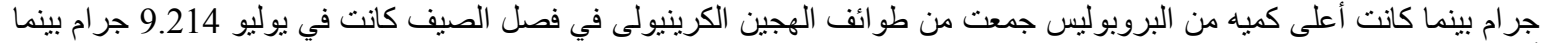

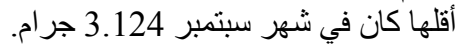

